\title{
Central 5-HTR2C in the Control of Metabolic Homeostasis
}

\section{OPEN ACCESS}

Edited by:

Etienne Challet,

Université de Strasbourg, France

Reviewed by:

Jin Kwon Jeong,

George Washington University,

United States

Lourdes Mounien,

Aix-Marseille Université, France

${ }^{*}$ Correspondence:

Ting Yao

xiaciweixiao@yeah.net

Ru Wang

wangru@sus.edu.cn

Tiemin Liu

tiemin_liu@fudan.edu.cn

${ }^{t}$ These authors have contributed equally to this work and

share first authorship

${ }^{\ddagger}$ These authors have contributed equally to this work and share last authorship

Specialty section:

This article was submitted to Neuroendocrine Science,

a section of the journal

Frontiers in Endocrinology

Received: 12 April 2021

Accepted: 06 July 2021

Published: 21 July 2021

Citation:

Yao T, He J, Cui Z, Wang R, Bao K, Huang Y, Wang R and Liu T (2021) Central 5-HTR2C in the Control of

Metabolic Homeostasis.

Front. Endocrinol. 12:694204. doi: 10.3389/fendo.2021.694204

\author{
Ting Yao ${ }^{1,2 \times t \neq}$, Jiehui He ${ }^{3 \dagger}$, Zhicheng Cui ${ }^{3}$, Ruwen Wang ${ }^{1}$, Kaixuan Bao ${ }^{4}$, Yiru Huang ${ }^{3}$, \\ Ru Wang ${ }^{1 * \pm}$ and Tiemin Liu $^{3,4,5,6 * \neq}$
}

${ }^{1}$ School of Kinesiology, Shanghai University of Sport, Shanghai, China, ${ }^{2}$ Department of Physiology and Pathophysiology, School of Basic Medical Sciences, Xi'an Jiaotong University School of Medicine, Xi'an, China, ${ }^{3}$ School of Life Sciences, Fudan University, Shanghai, China, ${ }^{4}$ Human Phenome Institute, Fudan University, Shanghai, China, 5 State Key Laboratory of Genetic Engineering, Fudan University, Shanghai, China, ${ }^{6}$ State Key Laboratory of Pharmaceutical Biotechnology, Nanjing University, Nanjing, China

The 5-hydroxytryptamine $2 \mathrm{C}$ receptor (5-HTR2C) is a class G protein-coupled receptor (GPCR) enriched in the hypothalamus and the brain stem, where it has been shown to regulate energy homeostasis, including feeding and glucose metabolism. Accordingly, 5HTR2C has been the target of several anti-obesity drugs, though the associated side effects greatly curbed their clinical applications. Dissecting the specific neural circuits of 5HTR2C-expressing neurons and the detailed molecular pathways of 5-HTR2C signaling in metabolic regulation will help to develop better therapeutic strategies towards metabolic disorders. In this review, we introduced the regulatory role of 5-HTR2C in feeding behavior and glucose metabolism, with particular focus on the molecular pathways, neural network, and its interaction with other metabolic hormones, such as leptin, ghrelin, insulin, and estrogens. Moreover, the latest progress in the clinical research on 5-HTR2C agonists was also discussed.

Keywords: 5-HTR2C, feeding behavior, glucose homeostasis, obesity, hypothalamus, neural network, energy metabolism, lorcaserin

\section{INTRODUCTION}

Serotonin, or 5-hydroxytryptamine (5-HT), is an essential neurotransmitter that has been shown to be involved in the regulation of multiple physiological and behavioral functions, including emotion, cognition, sleep, exercise, and energy homeostasis $(1,2)$. There are seven classes of receptors in the 5-HT family, most of which are G-protein coupled receptors (3, 4). Among them, 5-HTR2C has been shown as a key regulator for feeding and glucose homeostasis. Knock-out of 5-HTR2C in mice resulted in increased food intake, insulin resistance, and obesity $(5,6)$, while pharmacological activation of the 5-HTR2C inhibits food intake (7). Thus, 5-HTR2C has become a hot target for anti-obesity treatment. For example, the non-selective 5-HTR2C agonist D-Fenfluramine (d-Fen) (Table 2), and selective 5-HTR2C agonist lorcaserin (Table 2) were approved by Food and Drug Administration for body weight management. However, they were withdrawn due to associated side effects. A better understanding of the mechanism of 5-HTR2C on energy homeostasis will facilitate the development of improved drugs targeting 5-HTR2C pathways for metabolic diseases. In this review, we recapped the molecular mechanisms and discussed the neural circuits of 5-HTR2C in regulating energy metabolism. In addition, the functional interactions between 5-HTR2C and other 
appetite-regulatory signaling pathways were discussed. Since 5HTR2C has become one of the most promising targets for treating obesity, we also discussed the clinical application of 5HTR2C as a potential therapeutic target in treating metabolic diseases.

\section{5-HTR2C SIGNAL TRANSDUCTION}

5-HTR2C is one of the first sequenced and cloned 5-HT receptors (8). The gene coding 5 -HTR2C is located at chromosome $\mathrm{Xq} 24$ in humans. It contains three introns (instead of two, such as 5-HTR2A and 5-HTR2B) and encodes a protein product with seven transmembrane regions. There is more than $80 \%$ homology of 5 -HTR2C in the transmembrane regions among mice, rats, and humans (9). 5-HTR2C is widely expressed in the central nervous system (CNS) compared to the peripheral nervous system (10). In the CNS, 5-HTR2C is expressed in these known brain areas that are related to energy metabolism, including the ventral tegmental area (VTA), the arcuate nucleus (ARC), the nucleus tractus solitarius (NTS), paraventricular nucleus of the hypothalamus (PVN), and lateral parabrachial nucleus (LPBN) (11). Genetic studies with loss or gain function of 5-HTR2C indicate a key role of 5-HTR2C in these brain regions in maintaining energy homeostasis (12). Pharmacological studies using its agonists or antagonists also revealed that central 5- HTR2C is involved in various metabolic diseases such as diabetes and obesity (13). In line, a higher density of 5-HTR2C was found in the hypothalamus in PraderWilli syndrome (PWS) patients showing hyper appetite and obesity (14).

The best understood function of 5 -HTR2C is food intake regulation through 5-HTR2C action in pro-opiomelanocortin (POMC) neurons in the hypothalamus (Figure 1). Serotonin binding to 5-HTR2C leads to the dissociation of a heterotrimeric $\mathrm{G}$ protein that binds to the second intracellular loop of 5HTR2C. Upon dissociation, the subunit $G_{\alpha / q 11}$, activates phospholipase $\mathrm{C}$, generating inositol triphosphate (IP3) and diacylglycerol (DAG), which activates Protein Kinase C (PKC). PKC activates the extracellular regulated kinase (ERK) pathway, leading to the phosphorylation of c-Fos and POMC synthesis. POMC is processed into $\alpha$-melanocyte-stimulating hormone $(\alpha-$ $\mathrm{MSH}$ ) that activates neurons in the PVN via melanocortin 4 receptors (MC4Rs) (15). Activation of PVN neurons induces satiety, i.e., cessation of eating, an anorexic response.

Of note, 5-HTR2C is the only known GPCR whose mRNA undergoes post-transcriptional editing to yield different receptor isoforms (16). This RNA editing process further modulates the basal activity of 5-HTR2C and/or the sensitivity of 5-HTR2C (17). The 5-HTR2C mRNA is edited in 5 distinct sites (18) resulting in at least 33 distinct $\mathrm{mRNAs}$ and 25 distinct isoforms of the protein in humans (19). The activity of the 5-HTR2C is regulated through the ratio of these truncated to full-length receptors. An increase in the truncated receptor sequesters the full-length receptor intracellularly, decreasing 5-HTR2C signaling (20). Overexpression of fully-edited receptors decreased the expression of POMC in the hypothalamus and caused hyperphagia in mice (21). In addition, mutation of SNORD115, a small RNA that regulates alternative splicing of 5-HTR2C, is observed in most in PWS patients who are characterised by hyperphagia and obesity (14).

Taken together, 5-HTR2C is associated with multiple signal transduction pathways, mobilizing various intracellular signaling molecules. An in-depth understanding of the gene-editing processes of 5-HTR2C in the central regulation of metabolism may help to identify the differentially expressed targets for pharmacological operations and the development of new drugs.

\section{FEEDING BEHAVIOR}

\section{5-HTR2C in POMC Neurons in the ARC and NTS}

POMC neurons in the ARC are characterized as the first-order neurons that regulate energy balance in the hypothalamus (22). In the ARC, most of POMC neurons co-express 5-HTR2C (23) and receive inputs from serotoninergic nerve fibers terminate (24). 5-HTR2C has also been proved to regulate energy homeostasis. Mice with global mutation or knock-out of the 5HTR2C gene (2C-null) developed hyperphagia and obesity (Table 1) $(5,25,26)$, and 5-HTR2C agonist d-Fen was reported to suppress mice food intake, contributing to the anorexigenic effects (27). Electrophysiological studies showed that selective 5-HTR2C agonists, including m-chlorophenyl piperazine (mCPP), d-Fen (23), could activate ARC POMC neurons and stimulate POMC expression by increasing the mRNA level (28-30). ARC POMC neurons produce $\alpha-\mathrm{MSH}$, an endogenous agonist of MC4Rs (31-33). It was reported that the mutation of the $M C 4 R$ gene led to insensitivity to the anorectic effect of d-Fen (34), suggesting that the function of ARC 5-HTR2C required a central melanocortin pathway. In particular, the involved MC4R population was probably located at the single minded-1 (SIM1) neurons in the PVN, because the restoration of MC4Rs in SIM1 neurons in MC4R KO mice was sufficient to rescue anorexigenic effects caused by the 5-HTR2C agonist $(32,35,36)$. Moreover, deleting the 5-HTR2C gene only in POMC neurons (POMC-2C-null) increased mice food intake (Table 1) (15), while re-expressed 5-HTR2C in POMC neurons (POMC-2C-RE) could rescue this phenotype (Table 1) (25). Further, at the cellular level, transient receptor potential cation 5 (TrpC5) was required to activate POMC neurons by 5-HTR2C, as the intraperitoneal injections of 5-HTR2C agonist failed to suppress food intake in TrpC5 $\mathrm{KO}$ mice (37). Thus, the feeding inhibitory effect by activating 5-HTR2C was at least partly mediated by the POMC neurons in the ARC (Figure 2) $(23,38)$.

In addition to the ARC, NTS, a brainstem center for satiety signals, also contains substantial POMC-expressing neurons that co-express 5-HTR2C $(39,40)$. Studies have shown that 5-HT2CR in the NTS is involved in the anorexic effect of the two 5-HT2CR agonists, lorcaserin and WAY161,503 and chemogenetics activation of 5-HTR2C-expressing neurons in the NTS decrease food intake in mice (38). Interestingly, different from 


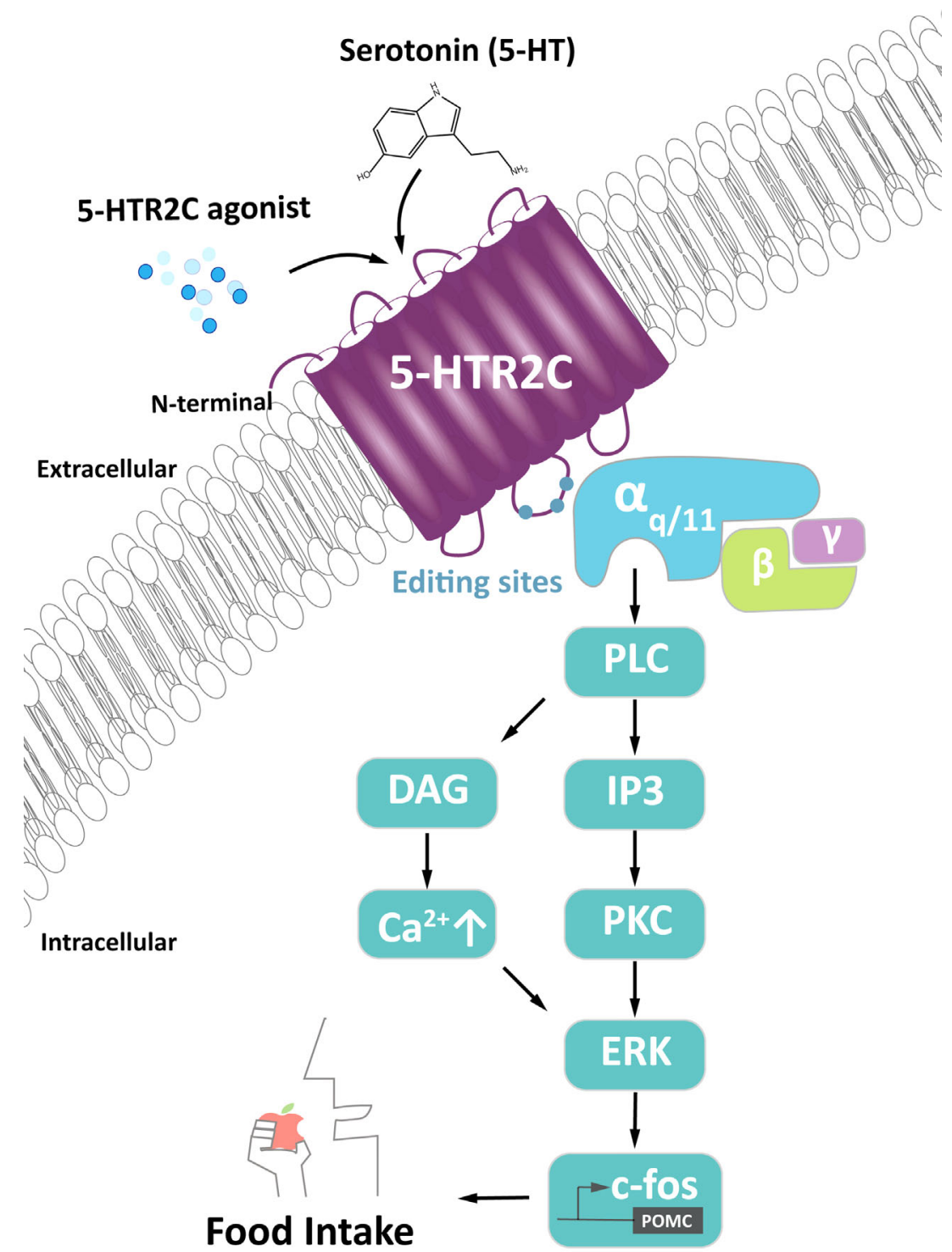

FIGURE 1 | Signaling of 5-HTR2C in POMC neurons generating food intake. Activation of $\alpha_{0 / 11}$ promotes phospholipase C (PLC) to produce diacylglycerol (DAG) and inositol-1,4,5-triphosphate (IP3). IP3 promotes release of intracellular calcium $\left(\mathrm{Ca}^{2+}\right)$ while DAG binds to downstream effector protein kinase C (PKC), both of which activates C-Fos via the extracellular regulated kinase pathway (ERK). C-Fos turns on the pro-opiomelanocortin (POMC) promoter, which signals to neurons regulating the food intake signal. This signal is also regulated by 5-HTR2C agonist and serotonin.

TABLE 1 | Phenotypes of the 5-HTR2C deficient mice.

\begin{tabular}{|c|c|c|c|c|c|c|c|}
\hline Mice Model & Body Weight & Fat Mass & Lean Mass & Food Intake & Binge-like Eating & Hepatic Glucose Production & Reference \\
\hline 2C-null & $\uparrow$ & $\uparrow$ & $\downarrow$ & $\uparrow$ & $\downarrow$ & $\uparrow$ & $(5,25)$ \\
\hline POMC-2C-null & $\uparrow$ & $\uparrow$ & $\downarrow$ & $\uparrow$ & $\downarrow$ & $\uparrow$ & $(15)$ \\
\hline POMC-2C-RE & $\leftrightarrow$ & $\leftrightarrow$ & $\leftrightarrow$ & $\leftrightarrow$ & I & $\leftrightarrow$ & (25) \\
\hline DA-2C-RE & / & / & / & $\uparrow$ & $\leftrightarrow$ & / & (15) \\
\hline $\mathrm{DA}-2 \mathrm{C}-\mathrm{KO}$ & / & / & / & $\uparrow$ & $\downarrow$ & / & (15) \\
\hline
\end{tabular}

'个', Increased; ' $\downarrow$ ', Reduced; ' $\leftrightarrow$ ', No change; 'l', Unknown. 2C-null is a loxed transcription blocker (loxTB) 5-HTR2C mouse line lacking functional 5-HTR2C globally; POMC-2C-null mice with previously characterized animals in which cre is constitutively (developmentally) expressed in POMC neurons to ablate 5-HTR2C specifically; POMC-2C-RE mice with 5-HTR2C reexpressed specifically and only in POMC neurons; DA-2C-RE mice with the expression of endogenous 5-HTR2C only in DA neurons; DA-2C-KO with deletion of endogenous 5-HTR2C only in DA neurons. 


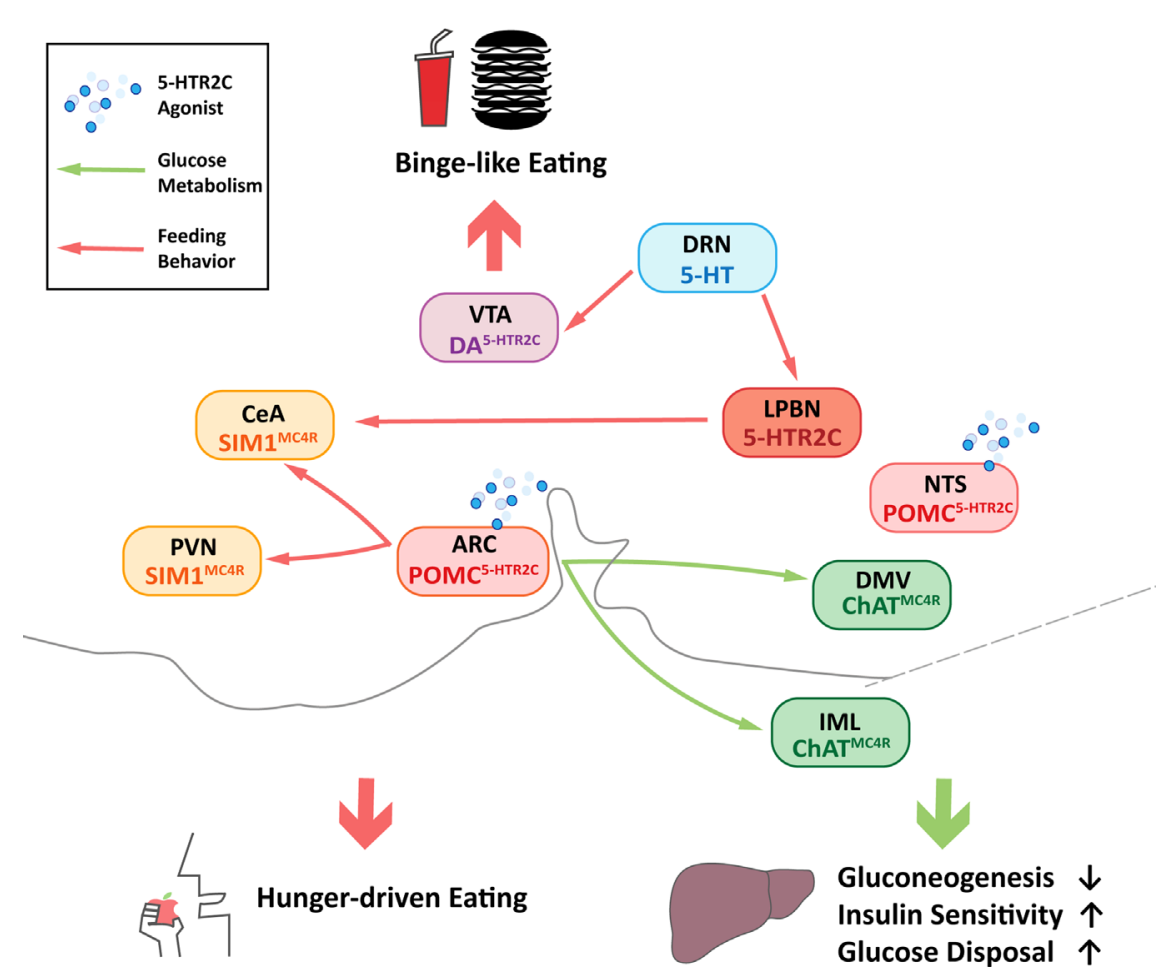

FIGURE 2 | Central neuronal circuits of 5-HTR2C that regulate feeding behavior and glucose homeostasis. Central Nervous System (CNS) 5-hydroxytryptamine receptor 2C (5-HTR2C) may regulate energy metabolism through neuronal circuits. Red arrows designate circuits that regulate three types of feeding behavior which are binge-like eating, sodium intake and hunger-driven eating, while the green arrows show the circuits that regulate glucose homeostasis by reducing gluconeogenesis, increasing insulin sensitivity and glucose disposal. Pink boxes indicate nuclei containing POMC neurons that co-express 5-HTR2C (POMC ${ }^{5-H T R 2 C)}$; Green boxes indicate nuclei containing cholinergic neurons that co-express melanocortin 4 receptors (ChATMC4R); Yellow boxes indicate nuclei containing single minded-1 (SIM1) neurons that co-express melanocortin 4 receptors (SIM1 ${ }^{\text {MC4R }}$ ); Light purple box indicates nuclei containing DA neurons that co-express 5-HTR2C (DA ${ }^{5-H T R 2 C}$ ); Light blue box indicates nuclei containing 5-HT neurons and orange box indicates nuclei containing a subset of neurons expressing 5-HTR2C. ARC, arcuate nucleus; NTS, nucleus tractus solitarius; PVN, paraventricular nucleus of the hypothalamus; CeA, central amygdala; LPBN, lateral parabrachial nucleus; DRN, dorsal raphe nucleus; VTA, ventral tegmental area; DMV, dorsal motor nucleus of the vagus; IML, intermediolateral nucleus.

ARC POMC neurons, NTS POMC neurons decreased food intake more significantly and rapidly, in other words, 5HTR2C agonist lorcaserin required a longer time to decrease mice food intake in the ARC as effectively as in the NTS $(38,41)$. Therefore, NTS POMC neurons appear to mediate the inhibitory effects of lorcaserin on feeding, but the downstream pathway remains elusive (Figure 2). Studies had shown that PVN and central amygdala (CeA) could be innervated by NTS POMC neurons (42). Both of them are key brain regions involved in the regulation of feeding behavior, but the roles of these brain regions warrant further investigation.

\section{5-HTR2C in Dopamine Neurons in the VTA}

Apart from homeostatic feeding, 5-HTR2C is also involved in hedonic feeding behaviors, defined as ingestion of a large amount of food in a short timeframe for pleasure $(43,44)$. The central dopamine (DA) system has been implicated in the pathophysiology of binge eating (45); 5-HT releasing neurons in the dorsal raphe nucleus (DRN) directly innervate DA neurons in VTA (46). In the VTA, DA neurons were proved to co-express 5-HTR2C (47), suggesting that 5-HTR2C probably interacted with VTA DA neurons to regulate binge eating. Moreover, intraperitoneal injections of 5-HTR2C agonists significantly suppressed binge-like eating in wild-type mice, while the 2C-null mice showed no effect (48). Indeed, specific knock-out of 5-HTR2C gene in the VTA DA neurons (DA-VTA$\mathrm{KO})$ blunted the suppression of binge-like eating by 5 -HTR2C agonist (Table 1) (48). These observations indicate that 5HTR2C can act downstream the DRN 5-HT neurons to inhibit food intake. However, the feeding control by VTA DA 5HTR2C-expressing neurons seemed specific to hedonic rather than hunger-driven eating, as re-expression of 5-HTR2C in DA neurons (DA-2C-RE) did not affect normal food intake in mice even when administered with the 5-HTR2C agonist (Table 1) (48). But the downstream neural circuits of the DA 5-HTR2Cexpressing neurons still remain unclear. Studies have found that administration of cocaine can increase DA releases in the nucleus accumbens (NAc), an effect that can be blocked by local injections of 5-HTR2C agonist in the VTA (49). Given the abundant connectivity between VTA neurons and the NAc, it would be interesting to know that DA 5-HTR2C neurons in the VTA regulate binge eating by projecting to the NAc (Figure 2). 


\section{5-HTR2C in the LPBN on Sodium Intake}

Sodium ions are important minerals for maintaining extracellular fluid and blood volume (50). Studies have found clues for 5-HTR2C in the LPBN to regulate sodium appetite (51). Ingestion of high-concentration sodium-containing food increased c-Fos expression in neurons that co-express 5HTR2C in the LPBN (52-54). Furthermore, specific activation of LPBN 5-HTR2C neurons rapidly suppressed sodium intake in mice. By contrast, inhibition of the 5-HTR2C neurons of LPBN increased the intake of sodium-containing foods (55). Furthermore, electrophysiological studies suggested an abundant connectivity between LPBN 5-HTR2C neurons and CeA (Figure 2) (54). In vivo optogenetics stimulation further indicated that LPBN 5-HTR2C neurons could suppress sodium appetite via projections to $\mathrm{CeA}$ (54). Moreover, raphe nuclei probably modulate the neurons in the LPBN through serotoninergic projections. The injection of retrobeads into the LPBN of wildtype mice showed co-localization of 5-HT and retro bead-labeled cells in the DRN and the median raphe nucleus (MnR) (54). In conclusion, LPBN 5-HTR2C neurons may receive 5-HT signals from median raphe nucleus (MRN)/DRN and project to the CeA to regulate sodium intake (Figure 2).

\section{ENERGY EXPENDITURE}

The 5-HT signaling pathway is closely related to individual energy storage and expenditure. Inhibiting the 5-HT signaling pathway can increase individual thermogenesis in mice (56). Studies found that the knock-out of 5-HTR2C affected the activity level and energy expenditure in mice. The mutant mice exhibited hyperactivity, and increased total energy expenditure, while reducing energy expenditure during exercise. At nine months old, elevated mRNA levels of uncoupling protein 2 (UCP2) were detected in the liver, skeletal muscle, and white adipose tissue of the mutant mice (57). The mice targeted restoration of POMC only within 5-HTR2C expressing cells showed sex differences in physical activity, energy expenditure, and the development of obesity (58). In addition, mutation of the 5-HTR2C gene can increase the mRNA level of UCP1 in brown adipose tissues and reduce fat accumulation in mice (59-61). In summary, 5-HTR2C can affect the energy expenditure of tissues or individuals in diverse ways.

\section{GLUCOSE HOMEOSTASIS}

In addition to regulating food intake, serotonin is essential in regulating glucose homeostasis. 5-HT produced by enterochromaffin cells in the gut can act as an paracrine signal modulating islet $\beta$ cell activity and proliferation $(62,63)$. It has been shown that 5 -HTR2B agonists could promote insulin secretion (64). Meanwhile, studies have revealed the role of 5HTR2C in the POMC neurons in mediating blood glucose, suggesting a central role of 5-HTR2C in glucose metabolism. Indeed, 2C-null mice manifested insulin resistance $(15,25)$, and POMC-2C-RE mice was sufficient to rescue the impairment
(Table 1) (6). On the other hand, 5-HTR2C agonist lorcaserin could significantly improve glucose and insulin tolerance in wildtype mice, and these effects were abolished in POMC gene deficient mice (POMC-NEO) and restored in POMC-2C-RE mice (65). Studies showed that the glycemic effect of 5-HTR2C in POMC neurons was mediated by cholinergic (ChAT) MC4Rs in dorsal motor nucleus of the vagus (DMV) and the intermediolateral nucleus (IML) $(32,65,66)$, which was different from the forebrain SIM1 MC4Rs implicated in feeding behavior, indicating the subsets of POMC 5-HTR2C neurons in controlling feeding behavior and glucose homeostasis might be different (Figure 2). It was shown that 5-HTR2C agonist $\mathrm{m}-\mathrm{CPP}$ and lorcaserin can improve glycemic control independently of body weight $(6,15,65,67)$. The improved glucose tolerance in mice by lorcaserin was found to be mediated by reducing the hepatic glucose production and improving glucose disposal, without change of insulin secretion (65) (Table 1 and Figure 2). Interestingly, a recent study showed that a subset of POMC neurons may have the ability to promote hepatic glucose production, which was speculated to be relevant with the heterogeneity of POMC neurons (68). Given the complex functions of POMC neurons in the brain, the relationship between this subset of POMC neurons and POMC 5-HTR2C neurons remains to be further elucidated. In analyzing the heterogeneity of different parts of the same tissue, the spatial transcriptomics studies may be helpful. Studies had preliminarily used the spatial transcriptome to reveal the heterogeneity of tumor tissue (69). Integrating the transcriptome profiles and projection patterns of individual neurons may help to clarify how POMC 5-HTR2C neurons process various stimuli at the singleneuron level.

\section{INTERACTION OF 5-HTR2C WITH BODYWEIGHT REGULATORY SIGNALS}

\section{Leptin}

Leptin, a key regulator for the metabolism, is secreted from adipocytes (70). It prevents bodyweight gain by suppressing feeding and increasing energy expenditure (71). Mutations of the gene encoding leptin in mice $(o b / o b)$ lead to severe obesity and increased appetite (72). The leptin receptor (LepR) mediates the effects of leptin on body weight, and it is involved in the majority of leptin's actions in the brain (73). Double fluorescent in situ hybridization experiments showed that in the hypothalamic, the neurons which express LepR also co-express 5-HTR2C, including the ARC and the ventromedial hypothalamus (VMH) $(74,75)$. However, selective knock-out of LepR in 5-HTR2C-expressed neurons exhibited neither hyperglycemia nor alteration in serum insulin or leptin concentrations (76). Further, single-cell transcriptomic data showed that the LepR-expressing POMC cells formed a molecularly distinct cluster relative to POMC neurons expressing the 5-HTR2C $(77,78)$, indicating that leptin probably affected systemic energy balance through different POMC neuronal subsets. In particular, Daniel D et al. clarified that brain 5HT neurons did not express LepR and therefore not directly 
responded to leptin (79). In conclusion, whether the leptin signaling pathway interacts with 5-HT remains controversial, which needs further research.

\section{Ghrelin}

Ghrelin is a stomach-derived body weight regulatory signal stimulating feeding via the growth hormone secretagogue receptors (GHSRs). The ghrelin signaling pathway interacts with 5-HT. The appetite-stimulating activity of ghrelin is shown to be mediated by the inhibition of serotonin release (80). GHSRs in ARC is expressed in $94 \%$ of nerve peptide Y (NPY) neurons and $8 \%$ of POMC neurons (81), and is co-localized with 5-HTR2C neurons. Studies have shown that the 5-HTR2C is dimerized with the GHSRs to inhibit its orexigenic activity (82). The activation of 5-HTR2B and 5-HTR2C reduced the gastric and hypothalamic secretion of ghrelin (83). 5-HTR2C agonist like lorcaserin inhibits the increase of plasma ghrelin level induced by fasting. Besides, 5-HTR2C antagonism reduces dimerization and increases GHSR-induced food intake, indicating that 5-HTR2C can change the regulation of ghrelin on feeding $(84,85)$. Overall, 5-HTR2C and its interaction with GHSR are probably a valuable target for designing new compounds to prevent obesity.

\section{Insulin}

Insulin efficiently crosses the blood-brain barrier via receptormediated transport (86). Besides, the insulin receptor is widely expressed in the CNS, including the cerebral cortex, hippocampus, and hypothalamus (87). Mice with targeted mutation in the 5HTR2C gene resulted in insulin resistance and type 2 diabetes (T2D), with antecedent hyperphagia and obesity $(26,88)$, suggesting an interaction of insulin with 5-HTR2C on energy metabolism. Infusion of insulin in the hypothalamic could briefly enhance 5-HT release in rostromedial hypothalamus (89), and systemic administration of 5-HTR2C agonist mCPP by osmotic minipumps could reduce fasting plasma insulin level through POMC neurons in diet-induced obesity (DIO) mice without altering blood glucose (90). However, single-cell transcriptomic data showed the subset of POMC neurons that expressing 5HTR2C and insulin receptor were not the same (77), which should be further investigated.

\section{Estrogens}

The gene encoding 5-HTR2C has been mapped to human chromosome $\mathrm{X}$, suggesting a sex-dependent role for 5-HTR2C signaling (91). When 5-HTR2C agonists and antagonists were used in elderly mice exposed to stress, different feeding phenotypes were found in females and males (92). When food is reduced due to stress, the female mice recovered more quickly than the male mice (92). In aged male mice, exposure to novelty stress promoted 5-HTR2C protein synthesis in PVN stress-specific neurons and activated neurons that expressed 5-HTR2C (93). In contrast, there was no change in 5-HTR2C and c-Fos co-positive cell counts in the PVN of aged female mice exposed to stress (93). It was unclear if these sex differences were due to gonadal hormones or the organizational effect, but estradiol was reported to enhance 5-HTR2C protein synthesis in the DRN region (94), caudal brainstem, and hypothalamus $(93,95)$.

\section{Cholecystokinin}

As a bodyweight regulatory signal, cholecystokinin(CCK), secreted by the gastrointestinal tract and neurons in brain, stimulates satiety and suppresses feeding behavior $(96,97)$. Some studies have found that CCK can act synergistically with 5-HT to inhibit food intake by simultaneously activating CCK-1 and 5-HTR3A $(98,99)$, and 5HTR1A are also involved in CCK induced anorexic behavior (100, 101). However, there is little research on the association between 5 HTR2C and CCK signaling in CNS (102), which is probably a direction for future research.

\section{NPY/AgRP}

Studies have confirmed co-expression of NPY and 5-HTR2C in the lateral hypothalamus, the basolateral nucleus and ARC (103105). Intraperitoneal injection with 5-HTR2C agonist lorcaserin could significantly reduce the expression of NPY mRNA in the ARC, while 5-HTR2C antagonist risperidone caused the opposite effect (103). In addition, injection of 5-HTR2A/2C agonist 1(2,5-dimethoxy-4-iodophenyl)-2-aminopropane (DOI) into the PVN, but not the perifornical hypothalamus and VMH, could suppress NPY-induced feeding behavior $(106,107)$. In summary, the effect of 5-HTR2C on feeding seems to be highly associated with NPY/AgRP signaling, and more research on how 5-HTR2C affects NPY/AgRP neurons is required for further investigation.

\section{CLINICAL APPLICATION}

\section{Obesity}

Obesity prevalence calls for new methods of appetite suppression and weight loss. Satiety and appetite control pathways have been widely studied in animals and humans, but the exact underlying molecular mechanism is still unclear $(108,109)$. Nowadays, some drugs used to treat obesity have side effects. At present, 5-HTR2C is one of the most promising targets for new weight-loss drugs. Many modulators targeting 5-HT signaling, including sibutramine (serotonin and adrenaline reuptake inhibitors) (Table 2), mCPP, and fenfluramine (also named as fluoxetine, selective serotonin reuptake inhibitors) (Table 2) have been used as appetite suppressants $(27,110,111)$. Sibutramine and fluoxetine can increase extracellular serotonin levels in vivo, non-selectively stimulate all postsynaptic subtypes, and then stimulate 5-HTR2C to suppress food intake $(112,113)$. Heisler (114) reported that $\mathrm{mCPP}$ did not inhibit food intake in 5HTR2C knock-out mice and weakened the swallowing effect of fenfluramine (serotonin releasing agent and reuptake inhibitor), demonstrating the key role of 5-HTR2C in satiety induction by d-fenfluramine. Fenfluramine, an effective treatment for obesity, sold as Pondimin ${ }^{\circledR} /$ Redux ${ }^{\circledR}$, reduces appetite. Fenfluramine binds weakly to the serotonin 5-HTR2C, d-Fen binds to and activates the serotonin 5-HTR2B and 5-HTR2C with high affinity and the serotonin 5-HTR2A with moderate affinity (115-117). However, fenfluramine is associated with side effects of valvular heart disease and pulmonary hypertension, prompting it to withdraw from clinical use $(118,119)$.

Lorcaserin is an effective and selective 5-HTR2C agonist that reduces food intake and body weight in rodents in a dose- 
TABLE 2 | 5-HTR2C related drugs in this review.

\begin{tabular}{|c|c|c|c|}
\hline Name & Mechanism of Action & Side Effect & Application \\
\hline Lorcaserin & selective 5 -HTR2C agonist & $\begin{array}{l}\text { headache, fatigue, nausea, dry mouth, and } \\
\text { constipation }\end{array}$ & weight-loss drug \\
\hline D-Fen & $\begin{array}{l}\text { serotonin releasing agent and reuptake } \\
\text { inhibitor }\end{array}$ & cardiac complications & weight-loss drug \\
\hline Sibutramine & $\begin{array}{l}\text { serotonin and adrenaline reuptake } \\
\text { inhibitor }\end{array}$ & stroke, myocardial infarction & weight-loss drug \\
\hline Fluoxetine & selective serotonin reuptake inhibitor & anorexia & $\begin{array}{l}\text { an approved drug to treat depression and obsessive- } \\
\text { compulsive disorder }\end{array}$ \\
\hline $\mathrm{m}-\mathrm{CPP}$ & agonist of 5-HTR2C and 5-HTR1B & anxiety, negative mood measured & $\begin{array}{l}\text { decrease food intake and enhance microstructural measures } \\
\text { of satiety }\end{array}$ \\
\hline
\end{tabular}

dependent manner (120). Lorcaserin was approved by Food and Drug Administration for weight management in adults with body mass index $(\mathrm{BMI}) \geq 30 \mathrm{~kg} / \mathrm{m}^{2}$ or BMI $\geq 27 \mathrm{~kg} / \mathrm{m}^{2}$ with at least one weight-related complication. Since 2013, lorcaserin has been sold in the United States under the name of Belviq ${ }^{\circledR}$. The safety and efficacy of lorcaserin have been determined by three phases III clinical trials, one cardiovascular (CV) outcome trial, and four randomized controlled trials (121-123). Animal experiments showed that after 28 days of treatment in dietinduced obesity rats, there was no aortic and mitral regurgitation in any treatment group (124). A 6-month randomized, placebocontrolled, double-blind clinical trial also found that lorcaserin could reduce weight and improve cardiac metabolic risk factors in obese adults, thus modifying circulating body weight regulatory signals associated with energy balance and decreasing the risk of cardiovascular disease (125). Recent follow-up data have shown that the drug probably increases cancer risk, and further research is needed. The role of 5-HTR2C in POMC neurons and the new role in neural circuits suggest that the new anti-obesity drugs act directly on the CNS, thereby reducing the negative effects caused by acting on the periphery, which will be discussed in the future.

\section{Diabetes}

As a chronic disease, the prevalence of $\mathrm{T} 2 \mathrm{D}$ continues to rise worldwide, highlighting the clinical need for a variety of treatment options. The current first-line drugs for T2D target peripheral tissue to improve blood glucose and insulin function $(126,127)$. 5-HTR2C has been found to regulate glucose homeostasis during weight loss, which is expected to become a candidate target $(128,129)$ for the treatment of diabetes. Yuan et al. discovered that the-759C/T polymorphism of the 5-HTR2C gene was associated with obesity and T2D (130). The lower frequency of-759T allele in the 5-HTR2C gene was associated with T2D but not associated with obesity in men and women (131), resulting from alleles type from promoter activity and transcriptional level, thus preventing the development of T2D.

A retrospective analysis of the Phase III BLOOM-DM study showed that lorcaserin combined with diet and exercise decreased blood glucose within 2 weeks (132-134). In the study of the effect of lorcaserin on weight loss in patients with $\mathrm{T} 2 \mathrm{D}$, lorcaserin could also decrease the Hemoglobin A1c of diabetic patients, providing direct evidence support for the treatment of diabetes. Besides, reducing fasting plasma glucose and Hemoglobin A1c was greater in people with no significant weight loss, suggesting that it could benefit blood sugar independent of weight loss. Besides, more clinical studies are needed to demonstrate this regulation in the future.

\section{Cardiovascular System}

Obesity and metabolic syndrome can increase the risk of cardiovascular disease. Weight-loss drugs can affect cardiovascular health by losing weight and directly acting on the cardiovascular system $(135,136)$. It was found that subcutaneous injection of 5-HTR2C agonist mCPP (3 mg/kg) had no significant effect on heart rate and meant arterial blood pressure (137). Lorcaserin, a selective 5-HTR2C agonist, did not seem to have a negative effect on the cardiovascular system at very high concentrations (125). Alpana P Shukla et al. (7) summarized the pharmacodynamic and pharmacokinetic characteristics of lorcaserin and discussed efficacy and safety data from major clinical trials. The bodyweight could be reduced by a certain dose of treatment. Therefore, the cardiac metabolic parameters could be significantly improved. In the CAMELLIATIMI 61 trial, the incidence of adverse cardiovascular events and conversion to $\mathrm{T} 2 \mathrm{D}$ in obese and overweight subjects with cardiovascular disease or multiple cardiovascular risk factors was assessed. It was concluded that the safety of the drug could be guaranteed.

In conclusion, as the first selective 5-HTR2C agonist approved for human weight control, the 5-HTR2C agonist lorcaserin has been widely used in clinical and scientific research after being launched in 2012. Although CAMELLIATIMI 61 research found no significant difference in cancer incidence during the first few months of treatment, the imbalance increased with the duration of lorcaserin, suggesting that the drug increased the risk of cancer. The cardiovascular effects of other anti-obesity drugs like liraglutide, bupropion/ naltrexone, and phentermine/topiramate remain uncertain (138). Due to the side effects of drugs, there is no better drug to treat obesity. Although 5-HTR2C is the target of several antiobesity drugs, its side effects limit their clinical application. However, the specific neural circuits of 5-HTR2C expressing neurons and the detailed molecular pathways of 5-HTR2C signaling on metabolic regulation will help to develop better treatment strategies for metabolic disorders. To solve the side 
effects caused by other drugs on the peripheral spectrum, future drugs that target the CNS will give us more inspiration.

\section{DISCUSSION}

In summary, the action of CNS 5-HTR2C neuron contributes to the regulation of energy homeostasis and have greatly advanced the understanding of the physiology and behavioral functions of 5-HTR2C in the brain. However, there are many questions. As a GPCR, understanding the 5-HTR2C gene-editing processes is helpful to study the weight-loss drug. However, the detailed molecular mechanisms remain unclear. Furthermore, there is growing interest in brain control of metabolism. Here, we summarized the 5-HTR2C related metabolic circuit of feeding behavior and glucose homeostasis in the brain, and we found that the mechanism of 5-HTR2C in the central cortex still needs to be further clarified. To explore the systemic effects of 5HTR2C, we also discussed the relationship between metabolic hormones and 5-HTR2C. From the perspective of clinical application, the functions of weight-loss drugs now are mostly concentrated on systemic administration, resulting in negative effects. In the future, 5-HTR2C in the brain may become a potential for the treatment of obesity and type 2 diabetes.

\section{REFERENCES}

1. Tecott LH. Serotonin and the Orchestration of Energy Balance. Cell Metab (2007) 6(5):352-61. doi: 10.1016/j.cmet.2007.09.012

2. Yabut JM, Crane JD, Green AE, Keating DJ, Khan WI, Steinberg GR. Emerging Roles for Serotonin in Regulating Metabolism: New Implications for an Ancient Molecule. Endocr Rev (2019) 40(4):1092-107. doi: 10.1210/ er.2018-00283

3. Barrera NP, Herbert P, Henderson RM, Martin IL, Edwardson JM. Atomic Force Microscopy Reveals the Stoichiometry and Subunit Arrangement of 5HT3 Receptors. Proc Natl Acad Sci USA (2005) 102(35):12595-600. doi: 10.1073/pnas.0503253102

4. Bennet H, Mollet IG, Balhuizen A, Medina A, Nagorny C, Bagge A, et al. Serotonin (5-HT) Receptor 2b Activation Augments Glucose-Stimulated Insulin Secretion in Human and Mouse Islets of Langerhans. Diabetologia (2016) 59(4):744-54. doi: 10.1007/s00125-015-3847-6

5. Tecott LH, Sun LM, Akana SF, Strack AM, Lowenstein DH, Dallman MF, et al. Eating Disorder and Epilepsy in Mice Lacking 5-HT2c Serotonin Receptors. Nature (1995) 374(6522):542-6. doi: 10.1038/374542a0

6. Xu Y, Berglund ED, Sohn JW, Holland WL, Chuang JC, Fukuda M, et al. 5HT2CRs Expressed by Pro-Opiomelanocortin Neurons Regulate Insulin Sensitivity in Liver. Nat Neurosci (2010) 13(12):1457-9. doi: 10.1038/ nn.2664

7. Shukla AP, Kumar RB, Aronne LJ. Lorcaserin Hcl for the Treatment of Obesity. Expert Opin Pharmacother (2015) 16(16):2531-8. doi: 10.1517/ 14656566.2015.1096345

8. Pazos A, Hoyer D, Palacios JM. Mesulergine, a Selective Serotonin-2 Ligand in the Rat Cortex, Does Not Label These Receptors in Porcine and Human Cortex: Evidence for Species Differences in Brain Serotonin-2 Receptors. Eur J Pharmacol (1984) 106(3):531-8. doi: 10.1016/0014-2999(84)90056-6

9. Bonhaus DW, Bach C, DeSouza A, Salazar FH, Matsuoka BD, Zuppan P, et al. The Pharmacology and Distribution of Human 5 Hydroxytryptamine2b (5-HT2B) Receptor Gene Products: Comparison With 5-HT2A and 5-HT2C Receptors. Br J Pharmacol (1995) 115(4):6228. doi: 10.1111/j.1476-5381.1995.tb14977.x

10. Pasqualetti M, Ori M, Castagna M, Marazziti D, Cassano GB, Nardi I. Distribution and Cellular Localization of the Serotonin Type 2C Receptor

\section{AUTHOR CONTRIBUTION}

$\mathrm{JH}, \mathrm{ZC}$, and RWW conceived and wrote the manuscript. KB modified the figure drawing. YH revised the overall framework of the article. TY, RW, and TL were responsible for the article structure, scientific logic, and innovative examination of the overall article. All authors contributed to the article and approved the submitted version.

\section{FUNDING}

The study was funded by a grant from the National Key Research and Development Program of China (2019YFA0801900, 2018YFA0800300), the National Natural Science Foundation of China (31971074), and the open fund of state key laboratory of Pharmaceutical Biotechnology, Nan-jing University, China (KFGN-201701).

\section{ACKNOWLEDGMENTS}

We wish to thank ZZ, YZ and FMX for critical reading of the manuscript.

Messenger RNA in Human Brain. Neuroscience (1999) 92(2):601-11. doi: 10.1016/s0306-4522(99)00011-1

11. Clemett DA, Punhani T, Duxon MS, Blackburn TP, Fone KC. Immunohistochemical Localisation of the 5-HT2C Receptor Protein in the Rat CNS. Neuropharmacology (2000) 39(1):123-32. doi: 10.1016/ s0028-3908(99)00086-6

12. Chou-Green JM, Holscher TD, Dallman MF, Akana SF. Repeated Stress in Young and Old 5-HT(2C) Receptor Knockout Mice. Physiol Behav (2003) 79 (2):217-26. doi: 10.1016/s0031-9384(03)00096-9

13. Palacios JM, Pazos A, Hoyer D. A Short History of the 5-HT(2C) Receptor: From the Choroid Plexus to Depression, Obesity and Addiction Treatment. Psychopharmacol (Berl) (2017) 234(9-10):1395-418. doi: 10.1007/s00213-0174545-5

14. Garfield AS, Davies JR, Burke LK, Furby HV, Wilkinson LS, Heisler LK, et al. Increased Alternate Splicing of Htr2c in a Mouse Model for Prader-Willi Syndrome Leads Disruption of 5HT(2C) Receptor Mediated Appetite. Mol Brain (2016) 9(1):95. doi: 10.1186/s13041-016-0277-4

15. Berglund ED, Liu C, Sohn JW, Liu T, Kim MH, Lee CE, et al. Serotonin 2C Receptors in Pro-Opiomelanocortin Neurons Regulate Energy and Glucose Homeostasis. J Clin Invest (2013) 123(12):5061-70. doi: 10.1172/ jci70338

16. Gurevich I, Tamir H, Arango V, Dwork AJ, Mann JJ, Schmauss C. Altered Editing of Serotonin 2C Receptor pre-mRNA in the Prefrontal Cortex of Depressed Suicide Victims. Neuron (2002) 34(3):349-56. doi: 10.1016/s08966273(02)00660-8

17. Berg KA, Cropper JD, Niswender CM, Sanders-Bush E, Emeson RB, Clarke WP. RNA-Editing of the 5-HT(2C) Receptor Alters Agonist-Receptor-Effector Coupling Specificity. Br J Pharmacol (2001) 134(2):386-92. doi: 10.1038/ sj.bjp. 0704255

18. Deffit SN, Hundley HA. To Edit or Not to Edit: Regulation of ADAR Editing Specificity and Efficiency. Wiley Interdiscip Rev RNA (2016) 7(1):113-27. doi: 10.1002/wrna.1319

19. Stamm S, Gruber SB, Rabchevsky AG, Emeson RB. The Activity of the Serotonin Receptor $2 \mathrm{C}$ is Regulated by Alternative Splicing. Hum Genet (2017) 136(9):1079-91. doi: 10.1007/s00439-017-1826-3

20. Zhang Z, Shen M, Gresch PJ, Ghamari-Langroudi M, Rabchevsky AG, Emeson RB, et al. Oligonucleotide-Induced Alternative Splicing of Serotonin 
2C Receptor Reduces Food Intake. EMBO Mol Med (2016) 8(8):878-94. doi: 10.15252/emmm.201506030

21. Morabito MV, Abbas AI, Hood JL, Kesterson RA, Jacobs MM, Kump DS, et al. Mice With Altered Serotonin 2C Receptor RNA Editing Display Characteristics of Prader-Willi Syndrome. Neurobiol Dis (2010) 39(2):16980. doi: $10.1016 /$ j.nbd.2010.04.004

22. Morton GJ, Cummings DE, Baskin DG, Barsh GS, Schwartz MW. Central Nervous System Control of Food Intake and Body Weight. Nature (2006) 443(7109):289-95. doi: 10.1038/nature05026

23. Heisler LK, Cowley MA, Tecott LH, Fan W, Low MJ, Smart JL, et al. Activation of Central Melanocortin Pathways by Fenfluramine. Science (2002) 297(5581):609-11. doi: 10.1126/science.1072327

24. Kiss J, Léránth C, Halász B. Serotoninergic Endings on VIP-Neurons in the Suprachiasmatic Nucleus and on ACTH-Neurons in the Arcuate Nucleus of the Rat Hypothalamus. A Combination of High Resolution Autoradiography and Electron Microscopic Immunocytochemistry. Neurosci Lett (1984) 44(2):119-24. doi: 10.1016/0304-3940(84)90068-5

25. Xu Y, Jones JE, Kohno D, Williams KW, Lee CE, Choi MJ, et al. 5-HT2CRs Expressed by Pro-Opiomelanocortin Neurons Regulate Energy Homeostasis. Neuron (2008) 60(4):582-9. doi: 10.1016/j.neuron.2008.09.033

26. Nonogaki K, Strack AM, Dallman MF, Tecott LH. Leptin-Independent Hyperphagia and Type 2 Diabetes in Mice With a Mutated Serotonin 5HT2C Receptor Gene. Nat Med (1998) 4(10):1152-6. doi: 10.1038/2647

27. Vickers SP, Clifton PG, Dourish CT, Tecott LH. Reduced Satiating Effect of D-Fenfluramine in Serotonin 5-HT(2C) Receptor Mutant Mice. Psychopharmacology (1999) 143(3):309-14. doi: 10.1007/s002130050952

28. Sohn JW, Xu Y, Jones JE, Wickman K, Williams KW, Elmquist JK. Serotonin 2C Receptor Activates a Distinct Population of Arcuate ProOpiomelanocortin Neurons via TRPC Channels. Neuron (2011) 71 (3):488-97. doi: 10.1016/j.neuron.2011.06.012

29. Doslikova B, Garfield AS, Shaw J, Evans ML, Burdakov D, Billups B, et al. 5HT2C Receptor Agonist Anorectic Efficacy Potentiated by 5-HT1B Receptor Agonist Coapplication: An Effect Mediated via Increased Proportion of ProOpiomelanocortin Neurons Activated. J Neurosci (2013) 33(23):9800-4. doi: 10.1523/jneurosci.4326-12.2013

30. Lam DD, Przydzial MJ, Ridley SH, Yeo GS, Rochford JJ, O’Rahilly S, et al. Serotonin 5-HT2C Receptor Agonist Promotes Hypophagia via Downstream Activation of Melanocortin 4 Receptors. Endocrinology (2008) 149(3):1323-8. doi: 10.1210/en.2007-1321

31. Fenselau H, Campbell JN, Verstegen AM, Madara JC, Xu J, Shah BP, et al. A Rapidly Acting Glutamatergic ARC $\rightarrow$ PVH Satiety Circuit Postsynaptically Regulated by $\alpha$-MSH. Nat Neurosci (2017) 20(1):42-51. doi: 10.1038/ nn.4442

32. Balthasar N, Dalgaard LT, Lee CE, Yu J, Funahashi H, Williams T, et al. Divergence of Melanocortin Pathways in the Control of Food Intake and Energy Expenditure. Cell (2005) 123(3):493-505. doi: 10.1016/ j.cell.2005.08.035

33. Garfield AS, Li C, Madara JC, Shah BP, Webber E, Steger JS, et al. A Neural Basis for Melanocortin-4 Receptor-Regulated Appetite. Nat Neurosci (2015) 18(6):863-71. doi: 10.1038/nn.4011

34. Heisler LK, Jobst EE, Sutton GM, Zhou L, Borok E, Thornton-Jones Z, et al. Serotonin Reciprocally Regulates Melanocortin Neurons to Modulate Food Intake. Neuron (2006) 51(2):239-49. doi: 10.1016/j.neuron.2006.06.004

35. Bergman B, Brismar B. Characteristics of Imprisoned Wife-Beaters. Forensic Sci Int (1994) 65(3):157-67. doi: 10.1016/0379-0738(94)90271-2

36. Xu Y, Jones JE, Lauzon DA, Anderson JG, Balthasar N, Heisler LK, et al. A Serotonin and Melanocortin Circuit Mediates D-Fenfluramine Anorexia. J Neurosci (2010) 30(44):14630-4. doi: 10.1523/JNEUROSCI.5412-09.2010

37. Gao Y, Yao T, Deng Z, Sohn JW, Sun J, Huang Y, et al. TrpC5 Mediates Acute Leptin and Serotonin Effects via Pomc Neurons. Cell Rep (2017) 18 (3):583-92. doi: 10.1016/j.celrep.2016.12.072

38. D’Agostino G, Lyons D, Cristiano C, Lettieri M, Olarte-Sanchez C, Burke LK, et al. Nucleus of the Solitary Tract Serotonin 5-HT(2C) Receptors Modulate Food Intake. Cell Metab (2018) 28(4):619-30.e5. doi: 10.1016/ j.cmet.2018.07.017

39. Fan W, Ellacott KL, Halatchev IG, Takahashi K, Yu P, Cone RD. Cholecystokinin-Mediated Suppression of Feeding Involves the Brainstem Melanocortin System. Nat Neurosci (2004) 7(4):335-6. doi: 10.1038/nn1214
40. Huo L, Grill HJ, Bjørbaek C. Divergent Regulation of Proopiomelanocortin Neurons by Leptin in the Nucleus of the Solitary Tract and in the Arcuate Hypothalamic Nucleus. Diabetes (2006) 55(3):567-73. doi: 10.2337/ diabetes.55.03.06.db05-1143

41. Zhan C, Zhou J, Feng Q, Zhang JE, Lin S, Bao J, et al. Acute and Long-Term Suppression of Feeding Behavior by POMC Neurons in the Brainstem and Hypothalamus, Respectively. J Neurosci: Off J Soc Neurosci (2013) 33 (8):3624-32. doi: 10.1523/jneurosci.2742-12.2013

42. Wang D, He X, Zhao Z, Feng Q, Lin R, Sun Y, et al. Whole-Brain Mapping of the Direct Inputs and Axonal Projections of POMC and AgRP Neurons. Front Neuroanat (2015) 9:40. doi: 10.3389/fnana.2015.00040

43. Patrick L. Eating Disorders: A Review of the Literature With Emphasis on Medical Complications and Clinical Nutrition. Altern Med Rev (2002) 7 (3):184-202.

44. Berthoud HR. Metabolic and Hedonic Drives in the Neural Control of Appetite: Who Is the Boss? Curr Opin Neurobiol (2011) 21(6):888-96. doi: 10.1016/j.conb.2011.09.004

45. van Gestel MA, Kostrzewa E, Adan RA, Janhunen SK. Pharmacological Manipulations in Animal Models of Anorexia and Binge Eating in Relation to Humans. Br J Pharmacol (2014) 171(20):4767-84. doi: 10.1111/bph.12789

46. Beier KT, Steinberg EE, DeLoach KE, Xie S, Miyamichi K, Schwarz L, et al. Circuit Architecture of VTA Dopamine Neurons Revealed by Systematic Input-Output Mapping. Cell (2015) 162(3):622-34. doi: 10.1016/ j.cell.2015.07.015

47. Bubar MJ, Cunningham KA. Distribution of Serotonin 5-HT2C Receptors in the Ventral Tegmental Area. Neuroscience (2007) 146(1):286-97. doi: 10.1016/j.neuroscience.2006.12.071

48. Xu P, He Y, Cao X, Valencia-Torres L, Yan X, Saito K, et al. Activation of Serotonin 2c Receptors in Dopamine Neurons Inhibits Binge-Like Eating in Mice. Biol Psychiatry (2017) 81(9):737-47. doi: 10.1016/j.biopsych. 2016.06.005

49. Navailles S, Moison D, Cunningham KA, Spampinato U. Differential Regulation of the Mesoaccumbens Dopamine Circuit by Serotonin2c Receptors in the Ventral Tegmental Area and the Nucleus Accumbens: An In Vivo Microdialysis Study With Cocaine. Neuropsychopharmacology (2008) 33(2):237-46. doi: 10.1038/sj.npp.1301414

50. Johnson AK, Thunhorst RL. The Neuroendocrinology of Thirst and Salt Appetite: Visceral Sensory Signals and Mechanisms of Central Integration. Front Neuroendocrinol (1997) 18(3):292-353. doi: 10.1006/frne.1997.0153

51. Castro L, Athanazio R, Barbetta M, Ramos AC, Angelo AL, Campos I, et al. Central 5-HT2B/2C and 5-HT3 Receptor Stimulation Decreases Salt Intake in Sodium-Depleted Rats. Brain Res (2003) 981(1-2):151-9. doi: 10.1016/ s0006-8993(03)03015-4

52. Yamamoto T, Shimura T, Sako N, Sakai N, Tanimizu T, Wakisaka S. C-Fos Expression in the Parabrachial Nucleus After Ingestion of Sodium Chloride in the Rat. Neuroreport (1993) 4(11):1223-6. doi: 10.1097/00001756199309000-00003

53. Geerling JC, Loewy AD. Sodium Deprivation and Salt Intake Activate Separate Neuronal Subpopulations in the Nucleus of the Solitary Tract and the Parabrachial Complex. J Comp Neurol (2007) 504(4):379-403. doi: $10.1002 /$ cne. 21452

54. Park S, Williams KW, Liu C, Sohn JW. A Neural Basis for Tonic Suppression of Sodium Appetite. Nat Neurosci (2020) 23(3):423-32. doi: 10.1038/s41593019-0573-2

55. Menani JV, Thunhorst RL, Johnson AK. Lateral Parabrachial Nucleus and Serotonergic Mechanisms in the Control of Salt Appetite in Rats. Am J Physiol (1996) 270(1 Pt 2):R162-8. doi: 10.1152/ajpregu.1996.270.1.R162

56. Oh C-M, Namkung J, Go Y, Shong KE, Kim K, Kim H, et al. Regulation of Systemic Energy Homeostasis by Serotonin in Adipose Tissues. Nat Commun (2015) 6(1):1-12. doi: 10.1038/ncomms7794

57. Nonogaki K, Abdallah L, Goulding EH, Bonasera SJ, Tecott LHJD. Hyperactivity and Reduced Energy Cost of Physical Activity in Serotonin 5-HT2C Receptor Mutant Mice. Diabetes (2003) 52(2):315-20. doi: 10.2337/ diabetes.52.2.315

58. Burke LK, Doslikova B, D’Agostino G, Greenwald-Yarnell M, Georgescu T, Chianese R, et al. Sex Difference in Physical Activity, Energy Expenditure and Obesity Driven by a Subpopulation of Hypothalamic POMC Neurons. Mol Metab (2016) 5: (3):245-52. doi: 10.1016/j.molmet.2016.01.005 
59. Fitzgerald LW, Iyer G, Conklin DS, Krause CM, Marshall A, Patterson JP, et al. Messenger RNA Editing of the Human Serotonin 5-HT 2C Receptor. Neuropsychopharmacology (1999) 21(1):82-90. doi: 10.1038/ sj.npp. 1395328

60. Burns CM, Chu H, Rueter SM, Hutchinson LK, Canton H, Sanders-Bush E, et al. Regulation of Serotonin-2C Receptor G-Protein Coupling by RNA Editing. Nature (1997) 387(6630):303-8. doi: 10.1038/387303a0

61. Kawahara Y, Grimberg A, Teegarden S, Mombereau C, Liu S, Bale TL, et al. Dysregulated Editing of Serotonin 2C Receptor mRNAs Results in Energy Dissipation and Loss of Fat Mass. J Neurosci (2008) 28(48):12834-44. doi: 10.1523/JNEUROSCI.3896-08.2008

62. Sanger GJ. 5-Hydroxytryptamine and the Gastrointestinal Tract: Where Next? Trends Pharmacol Sci (2008) 29(9):465-71. doi: 10.1016/ j.tips.2008.06.008

63. Fung TC, Vuong HE, Luna CDG, Pronovost GN, Aleksandrova AA, Riley NG, et al. Intestinal Serotonin and Fluoxetine Exposure Modulate Bacterial Colonization in the Gut. Nat Microbiol (2019) 4(12):2064-73. doi: 10.1038/ s41564-019-0540-4

64. Georgescu T, Lyons D, Heisler LK. Role of Serotonin in Body Weight, Insulin Secretion and Glycaemic Control. J Neuroendocrinol (2021) 33(4): e12960. doi: 10.1111/jne.12960

65. Burke LK, Ogunnowo-Bada E, Georgescu T, Cristiano C, de Morentin PBM, Valencia Torres L, et al. Lorcaserin Improves Glycemic Control via a Melanocortin Neurocircuit. Mol Metab (2017) 6(10):1092-102. doi: 10.1016/j.molmet.2017.07.004

66. Rossi J, Balthasar N, Olson D, Scott M, Berglund E, Lee CE, et al. Melanocortin-4 Receptors Expressed by Cholinergic Neurons Regulate Energy Balance and Glucose Homeostasis. Cell Metab (2011) 13(2):195204. doi: 10.1016/j.cmet.2011.01.010

67. Wade JM, Juneja P, MacKay AW, Graham J, Havel PJ, Tecott LH, et al. Synergistic Impairment of Glucose Homeostasis in Ob/Ob Mice Lacking Functional Serotonin 2C Receptors. Endocrinology (2008) 149(3):955-61. doi: 10.1210/en.2007-0927

68. Kwon E, Joung HY, Liu SM, Chua SCJr., Schwartz GJ, Jo YH. Optogenetic Stimulation of the Liver-Projecting Melanocortinergic Pathway Promotes Hepatic Glucose Production. Nat Commun (2020) 11(1):6295. doi: 10.1038/ s41467-020-20160-w

69. Berglund E, Maaskola J, Schultz N, Friedrich S, Marklund M, Bergenstråhle J, et al. Spatial Maps of Prostate Cancer Transcriptomes Reveal an Unexplored Landscape of Heterogeneity. Nat Commun (2018) 9(1):2419. doi: 10.1038/s41467-018-04724-5

70. Leibel RL, Chung WK, Chua SCJr. The Molecular Genetics of Rodent Single Gene Obesities. J Biol Chem (1997) 272(51):31937-40. doi: 10.1074/ jbc.272.51.31937

71. Trayhurn P, Thurlby PL, James WP. Thermogenic Defect in Pre-Obese Ob/ Ob Mice. Nature (1977) 266(5597):60-2. doi: 10.1038/266060a0

72. Frederich RC, Hamann A, Anderson S, Löllmann B, Lowell BB, Flier JS. Leptin Levels Reflect Body Lipid Content in Mice: Evidence for Diet-Induced Resistance to Leptin Action. Nat Med (1995) 1(12):1311-4. doi: 10.1038/ nm1295-1311

73. Tartaglia LA. The Leptin Receptor. J Biol Chem (1997) 272(10):6093-6. doi: $10.1074 / \mathrm{jbc} .272 .10 .6093$

74. Yadav VK, Oury F, Suda N, Liu ZW, Gao XB, Confavreux C, et al. A Serotonin-Dependent Mechanism Explains the Leptin Regulation of Bone Mass, Appetite, and Energy Expenditure. Cell (2009) 138(5):976-89. doi: $10.1016 /$ /.cell.2009.06.051

75. Pasqualetti M, Ori M, Marazziti D, Castagna M, Nardi I. Distribution of 5HT2c and 5-Ht5a Receptor mRNA in Human Brain. Ann NY Acad Sci (1998) 861:245. doi: 10.1111/j.1749-6632.1998.tb10202.x

76. Rupp AC, Allison MB, Jones JC, Patterson CM, Faber CL, Bozadjieva N, et al. Specific Subpopulations of Hypothalamic Leptin Receptor-Expressing Neurons Mediate the Effects of Early Developmental Leptin Receptor Deletion on Energy Balance. Mol Metab (2018) 14:130-8. doi: 10.1016/ j.molmet.2018.06.001

77. Lam BYH, Cimino I, Polex-Wolf J, Nicole Kohnke S, Rimmington D, Iyemere V, et al. Heterogeneity of Hypothalamic Pro-OpiomelanocortinExpressing Neurons Revealed by Single-Cell RNA Sequencing. Mol Metab (2017) 6(5):383-92. doi: 10.1016/j.molmet.2017.02.007
78. Quarta C, Claret M, Zeltser LM, Williams KW, Yeo GSH, Tschöp MH, et al. POMC Neuronal Heterogeneity in Energy Balance and Beyond: An Integrated View. Nat Metab (2021) 3(3):299-308. doi: 10.1038/s42255021-00345-3

79. Lam DD, Leinninger GM, Louis GW, Garfield AS, Marston OJ, Leshan RL, et al. Leptin Does Not Directly Affect CNS Serotonin Neurons to Influence Appetite. Cell Metab (2011) 13(5):584-91. doi: 10.1016/j.cmet.2011.03.016

80. Brunetti L, Recinella L, Orlando G, Michelotto B, Di Nisio C, Vacca M. Effects of Ghrelin and Amylin on Dopamine, Norepinephrine and Serotonin Release in the Hypothalamus. Eur J Pharmacol (2002) 454(2-3):189-92. doi: 10.1016/s0014-2999(02)02552-9

81. Benoit S, Schwartz M, Baskin D, Woods SC, Seeley RJ. CNS Melanocortin System Involvement in the Regulation of Food Intake. Horm Behav (2000) 37(4):299-305. doi: 10.1006/hbeh.2000.1588

82. Schellekens H, De Francesco PN, Kandil D, Theeuwes WF, McCarthy T, van Oeffelen WE, et al. Ghrelin's Orexigenic Effect Is Modulated via a Serotonin 2c Receptor Interaction. ACS Chem Neurosci (2015) 6(7):1186-97. doi: $10.1021 / \mathrm{cn} 500318 \mathrm{q}$

83. Hattori T, Yakabi K, Takeda H. Cisplatin-Induced Anorexia and Ghrelin. Vitam Horm (2013) 92:301-17. doi: 10.1016/B978-0-12-410473-0.00012-X

84. Lu S, Guan JL, Wang QP, Uehara K, Yamada S, Goto N, et al. Immunocytochemical Observation of Ghrelin-Containing Neurons in the Rat Arcuate Nucleus. Neurosci Lett (2002) 321(3):157-60. doi: 10.1016/ s0304-3940(01)02544-7

85. Cowley MA, Smith RG, Diano S, Tschöp M, Pronchuk N, Grove KL, et al. The Distribution and Mechanism of Action of Ghrelin in the CNS Demonstrates a Novel Hypothalamic Circuit Regulating Energy Homeostasis. Neuron (2003) 37 (4):649-61. doi: 10.1016/s0896-6273(03)00063-1

86. King GL, Johnson SM. Receptor-Mediated Transport of Insulin Across Endothelial Cells. Science (1985) 227(4694):1583-6. doi: 10.1126/ science. 3883490

87. Havrankova J, Roth J, Brownstein M. Insulin Receptors are Widely Distributed in the Central Nervous System of the Rat. Nature (1978) 272 (5656):827-9. doi: 10.1038/272827a0

88. Bonasera SJ, Tecott LH. Mouse Models of Serotonin Receptor Function: Toward a Genetic Dissection of Serotonin Systems. Pharmacol Ther (2000) 88(2):133-42. doi: 10.1016/s0163-7258(00)00087-5

89. Orosco M, Rouch C, Gerozissis K. Activation of Hypothalamic Insulin by Serotonin is the Primary Event of the Insulin-Serotonin Interaction Involved in the Control of Feeding. Brain Res (2000) 872(1-2):64-70. doi: 10.1016/ s0006-8993(00)02449-5

90. Zhou L, Sutton GM, Rochford JJ, Semple RK, Lam DD, Oksanen LJ, et al. Serotonin 2C Receptor Agonists Improve Type 2 Diabetes via Melanocortin4 Receptor Signaling Pathways. Cell Metab (2007) 6(5):398-405. doi: 10.1016/j.cmet.2007.10.008

91. Lappalainen J, Zhang L, Dean M, Oz M, Ozaki N, Yu D-h, et al. Identification, Expression, and Pharmacology of a Cys23-Ser23 Substitution in the Human 5-HT2c Receptor Gene (HTR2C). Genomics (1995) 27(2):274-9. doi: 10.1006/geno.1995.1042

92. Qiu J, Xue C, Bosch MA, Murphy JG, Fan W, Rønnekleiv OK, et al. Serotonin 5-Hydroxytryptamine2c Receptor Signaling in Hypothalamic Proopiomelanocortin Neurons: Role in Energy Homeostasis in Females. Mol Pharmacol (2007) 72(4):885-96. doi: 10.1124/mol.107.038083

93. Yamada C, Sadakane C, Nahata M, Saegusa Y, Nakagawa K, Okubo N, et al. Serotonin 2C Receptor Contributes to Gender Differences in Stress-Induced Hypophagia in Aged Mice. Psychoneuroendocrinology (2015) 55:81-93. doi: 10.1016/j.psyneuen.2015.02.006

94. Henderson JA, Bethea CL. Differential Effects of Ovarian Steroids and Raloxifene on Serotonin $1 \mathrm{~A}$ and $2 \mathrm{C}$ Receptor Protein Expression in Macaques. Endocrine (2008) 33(3):285-93. doi: 10.1007/s12020-008-9087-5

95. Santollo J, Yao D, Neal-Perry G, Etgen AM. Middle-Aged Female Rats Retain Sensitivity to the Anorexigenic Effect of Exogenous Estradiol. Behav Brain Res (2012) 232(1):159-64. doi: 10.1016/j.bbr.2012.04.010

96. Noble F, Roques BJ. Cholecystokinin Peptides in Brain Function. Handb Neurochem Mol Neurobiol (2006), 545-71. doi: 10.1007/978-0-387-30381-9_24

97. Ivy A, Oldberg EJA. A Hormone Mechanism for Gall-Bladder Contraction and Evacuation. JoP-LC (1928) 86(3):599-613. doi: 10.1152/ajplegacy. 1928.86.3.599 
98. Hayes MR, Covasa MJP. CCK and 5-HT Act Synergistically to Suppress Food Intake Through Simultaneous Activation of CCK-1 and 5-HT3 Receptors. Peptides (2005) 26(11):2322-30. doi: 10.1016/j.peptides. 2005.03.045

99. Hayes MR, Covasa M. Dorsal Hindbrain 5-HT3 Receptors Participate in Control of Meal Size and Mediate CCK-Induced Satiation. JBr (2006) 1103 (1):99-107. doi: 10.1016/j.brainres.2006.05.058

100. Hayes MR, Moore RL, Shah SM, Covasa MJ. 5-HT3 Receptors Participate in CCK-Induced Suppression of Food Intake by Delaying Gastric Emptying. AJoP-R Integrative Physiol C (2004) 287(4):R817-R23. doi: 10.1152/ ajpregu.00295.2004

101. Voigt J-P, Fink H, Marsden CJ. Evidence for the Involvement of the 5-HT 1A Receptor in CCK Induced Satiety in Rats. N-Ssaop (1995) 351(3):217-20. doi: 10.1007/BF00233239

102. Asarian L, Geary N, Langhans WJA. Serotonin 2C Receptor (5HT2CR) Signaling is Necessary for, and Dissociates the Neural Pathways of, the Satiating Effects of Cholecystokinin (CCK) and Glucagon-Like Peptide-1 (GLP-1). Appetite (2008) 2(51):352. doi: 10.1016/j.appet.2008.04.029

103. Wan XQ, Zeng F, Huang XF, Yang HQ, Wang L, Shi YC, et al. Risperidone Stimulates Food Intake and Induces Body Weight Gain via the Hypothalamic Arcuate Nucleus 5-HT2c Receptor-NPY Pathway. CNS Neurosci Ther (2020) 26(5):558-66. doi: 10.1111/cns.13281

104. Bonn M, Schmitt A, Lesch K-P, Van Bockstaele E, Asan EJBS. Function. Serotonergic Innervation and Serotonin Receptor Expression of NPY-Producing Neurons in the Rat Lateral and Basolateral Amygdaloid Nuclei. Brain Struct Funct (2013) 218(2):421-35. doi: 10.1007/s00429-0120406-5

105. Bocchio M, McHugh SB, Bannerman DM, Sharp T, Capogna MJ. Serotonin, Amygdala and Fear: Assembling the Puzzle. Finc (2016) 10:24. doi: 10.3389/ fncir.2016.00024

106. Currie PJ, Saxena N, Tu AYJN. 5-HT2A/2C Receptor Antagonists in the Paraventricular Nucleus Attenuate the Action of DOI on NPY-Stimulated Eating. Neuroreport (1999) 10(14):3033-6. doi: 10.1097/00001756199909290-00029

107. Currie PJ, Coscina DVJN. Stimulation of 5-HT2A/2C Receptors Within Specific Hypothalamic Nuclei Differentially Antagonizes NPY-Induced Feeding. Neuroreport (1997) 8(17):3759-62. doi: 10.1097/00001756199712010-00020

108. Isaac M. Serotonergic 5-HT2C Receptors as a Potential Therapeutic Target for the Design Antiepileptic Drugs. Curr Topics Medicinal Chem (2005) 5 (1):59-67. doi: 10.2174/1568026053386980

109. Ahima RS, Antwi DA. Brain Regulation of Appetite and Satiety. Endocrinol Metab Clin North Am (2008) 37(4):811-23. doi: 10.1016/j.ecl.2008.08.005

110. Dalton GL, Lee MD, Kennett GA, Dourish CT, Clifton PG. Serotonin 1B and 2C Receptor Interactions in the Modulation of Feeding Behaviour in the Mouse. Psychopharmacology (2006) 185(1):45-57. doi: 10.1007/s00213-0050212-3

111. Dalton GL, Lee MD, Kennett GA, Dourish CT, Clifton PG. mCPP-Induced Hyperactivity in 5-HT2C Receptor Mutant Mice Is Mediated by Activation of Multiple 5-HT Receptor Subtypes. Neuropharmacology (2004) 46(5):66371. doi: 10.1016/j.neuropharm.2003.11.012

112. Higgs S, Cooper AJ, Barnes NM. Reversal of Sibutramine-Induced Anorexia With a Selective 5-HT(2C) Receptor Antagonist. Psychopharmacology (2011) 214(4):941-7. doi: 10.1007/s00213-010-2106-2

113. Halford JC, Harrold JA. 5-HT(2C) Receptor Agonists and the Control of Appetite. Handb Exp Pharmacol (2012) 209):349-56. doi: 10.1007/978-3642-24716-3_16

114. Heisler LK, Chu HM, Tecott LH. Epilepsy and Obesity in Serotonin 5-HT2C Receptor Mutant Mice. Ann NY Acad Sci (1998) 861:74-8. doi: 10.1111/ j.1749-6632.1998.tb10175.x

115. Garattini S, Mennini T, Bendotti C, Invernizzi R, Samanin R. Neurochemical Mechanism of Action of Drugs Which Modify Feeding via the Serotoninergic System. Appetite (1986) 7 Suppl:15-38. doi: 10.1016/s01956663(86)80050-2

116. Oluyomi AO, Gibson EL, Barnfield AM, Curzon G. D-Fenfluramine and DNorfenfluramine Hypophagias Do Not Require Increased Hypothalamic 5Hydroxytryptamine Release. Eur J Pharmacol (1994) 264(1):111-5. doi: 10.1016/0014-2999(94)90646-7
117. Gibson EL, Kennedy AJ, Curzon G. D-Fenfluramine- and D-NorfenfluramineInduced Hypophagia: Differential Mechanisms and Involvement of Postsynaptic 5-HT Receptors. Eur J Pharmacol (1993) 242(1):83-90. doi: 10.1016/0014-2999(93)90013-8

118. Khan MA, Herzog CA, St Peter JV, Hartley GG, Madlon-Kay R, Dick CD, et al. The Prevalence of Cardiac Valvular Insufficiency Assessed by Transthoracic Echocardiography in Obese Patients Treated With AppetiteSuppressant Drugs. N Engl J Med (1998) 339(11):713-8. doi: 10.1056/ NEJM199809103391101

119. Gardin JM, Schumacher D, Constantine G, Davis KD, Leung C, Reid CL. Valvular Abnormalities and Cardiovascular Status Following Exposure to Dexfenfluramine or Phentermine/Fenfluramine. Jama (2000) 283(13):17039. doi: $10.1001 /$ jama.283.13.1703

120. Thomsen WJ, Grottick AJ, Menzaghi F, Reyes-Saldana H, Espitia S, Yuskin D, et al. Lorcaserin, A Novel Selective Human 5-Hydroxytryptamine2c Agonist: In Vitro and In Vivo Pharmacological Characterization. J Pharmacol Exp Ther (2008) 325(2):577-87. doi: 10.1124/jpet.107.133348

121. Smith SR, Weissman NJ, Anderson CM, Sanchez M, Chuang E, Stubbe S, et al. Multicenter, Placebo-Controlled Trial of Lorcaserin for Weight Management. N Engl J Med (2010) 363(3):245-56. doi: 10.1056/ NEJMoa0909809

122. Fidler MC, Sanchez M, Raether B, Weissman NJ, Smith SR, Shanahan WR, et al. A One-Year Randomized Trial of Lorcaserin for Weight Loss in Obese and Overweight Adults: The BLOSSOM Trial. J Clin Endocrinol Metab (2011) 96(10):3067-77. doi: 10.1210/jc.2011-1256

123. Chan EW, He Y, Chui CS, Wong AY, Lau WC, Wong IC. Efficacy and Safety of Lorcaserin in Obese Adults: A Meta-Analysis of 1-Year Randomized Controlled Trials (RCTs) and Narrative Review on Short-Term RCTs. Obes Reviews: An Off J Int Assoc Study Obes (2013) 14(5):383-92. doi: 10.1111/ obr.12015

124. Higgins GA, Desnoyer J, Van Niekerk A, Silenieks LB, Lau W, Thevarkunnel $S$, et al. Characterization of the 5-HT2C Receptor Agonist Lorcaserin on Efficacy and Safety Measures in a Rat Model of Diet-Induced Obesity. Pharmacol Res Perspect (2015) 3(1):e00084. doi: 10.1002/prp2.84

125. Tuccinardi D, Farr OM, Upadhyay J, Oussaada SM, Mathew H, Paschou SA, et al. Lorcaserin Treatment Decreases Body Weight and Reduces Cardiometabolic Risk Factors in Obese Adults: A Six-Month, Randomized, Placebo-Controlled, Double-Blind Clinical Trial. Diabetes Obes Metab (2019) 21(6):1487-92. doi: 10.1111/dom.13655

126. Intensive Blood-Glucose Control With Sulphonylureas or Insulin Compared With Conventional Treatment and Risk of Complications in Patients With Type 2 Diabetes (UKPDS 33). UK Prospective Diabetes Study (UKPDS) Group. Lancet (1998) 352(9131):837-53. doi: 10.1016/S0140-6736(98)07019-6

127. Effect of Intensive Blood-Glucose Control With Metformin on Complications in Overweight Patients With Type 2 Diabetes (UKPDS 34). UK Prospective Diabetes Study (UKPDS) Group. Lancet (1998) 352(9131):854-65. doi: 10.1016/S0140-6736(98)07037-8

128. Meyer J, Saam W, Mossner R, Cangir O, Ortega GR, Tatschner T, et al. Evolutionary Conserved Microsatellites in the Promoter Region of the 5Hydroxytryptamine Receptor 2C Gene (HTR2C) are Not Associated With Bipolar Disorder in Females. J Neural Transm (2002) 109(5-6):939-46. doi: $10.1007 / s 007020200077$

129. Hill MJ, Reynolds GP. 5-HT2C Receptor Gene Polymorphisms Associated With Antipsychotic Drug Action Alter Promoter Activity. Brain Res (2007) 1149:14-7. doi: 10.1016/j.brainres.2007.02.038

130. Yuan X, Yamada K, Ishiyama-Shigemoto S, Koyama W, Nonaka K. Identification of Polymorphic Loci in the Promoter Region of the Serotonin 5-HT2C Receptor Gene and Their Association With Obesity and Type II Diabetes. Diabetologia (2000) 43(3):373-6. doi: 10.1007/ s001250050056

131. Iordanidou M, Tavridou A, Vasiliadis MV, Arvanitidis KI, Petridis J, Christakidis D, et al. The -759c/T Polymorphism of the 5-HT2C Receptor is Associated With Type 2 Diabetes in Male and Female Caucasians. Pharmacogenetics Genomics (2008) 18(2):153-9. doi: 10.1097/ FPC.0b013e3282f4ae93

132. Magkos F, Nikonova E, Fain R, Zhou S, Ma T, Shanahan W. Effect of Lorcaserin on Glycemic Parameters in Patients With Type 2 Diabetes Mellitus. Obesity (2017) 25(5):842-9. doi: 10.1002/oby.21798 
133. O’Neil PM, Smith SR, Weissman NJ, Fidler MC, Sanchez M, Zhang J, et al. Randomized Placebo-Controlled Clinical Trial of Lorcaserin for Weight Loss in Type 2 Diabetes Mellitus: The BLOOM-DM Study. Obesity (2012) 20 (7):1426-36. doi: 10.1038/oby.2012.66

134. Handelsman Y, Fain R, Wang Z, Li X, Fujioka K, Shanahan W. Lorcaserin Treatment Allows for Decreased Number Needed to Treat for Weight and Glycemic Parameters in Week 12 Responders With $>/=5 \%$ Weight Loss. Postgraduate Med (2016) 128(8):740-6. doi: 10.1080/00325481. 2016.1240591

135. Ma C, Avenell A, Bolland M, Hudson J, Stewart F, Robertson C, et al. Effects of Weight Loss Interventions for Adults Who Are Obese on Mortality, Cardiovascular Disease, and Cancer: Systematic Review and Meta-Analysis. BMJ (2017) 359:j4849. doi: 10.1136/bmj.j4849

136. Carbone S, Lavie CJ, Arena R. Obesity and Heart Failure: Focus on the Obesity Paradox. Mayo Clinic Proc (2017) 92(2):266-79. doi: 10.1016/ j.mayocp.2016.11.001

137. Stiedl O, Misane I, Koch M, Pattij T, Meyer M, Ogren SO. Activation of the Brain 5-HT2C Receptors Causes Hypolocomotion Without Anxiogenic-Like
Cardiovascular Adjustments in Mice. Neuropharmacology (2007) 52(3):94957. doi: 10.1016/j.neuropharm.2006.10.012

138. Cataldi M, Cignarelli A, Giallauria F, Muscogiuri G, Barrea L, Savastano S, et al. Cardiovascular Effects of Antiobesity Drugs: Are the New Medicines All the Same? Int J Obes Suppl (2020) 10(1):14-26. doi: 10.1038/s41367-0200015-3

Conflict of Interest: The authors declare that the research was conducted in the absence of any commercial or financial relationships that could be construed as a potential conflict of interest.

Copyright (c) 2021 Yao, He, Cui, Wang, Bao, Huang, Wang and Liu. This is an openaccess article distributed under the terms of the Creative Commons Attribution License (CC BY). The use, distribution or reproduction in other forums is permitted, provided the original author(s) and the copyright owner(s) are credited and that the original publication in this journal is cited, in accordance with accepted academic practice. No use, distribution or reproduction is permitted which does not comply with these terms. 